\title{
The Development of Germicidal Air Purifier by Employing Ultraviolet System in Controlling Airborne Bacteria
}

\author{
Nur Atik, ${ }^{1}$ Siska Widya Dewi Kusumah, ${ }^{2}$ Fitria Mahrunnisa, ${ }^{2}$ Winni Maharani, ${ }^{3}$ \\ Windi Nurdiawan, ${ }^{4}$ Putu Indra Cyntia Dewi, ${ }^{1}$ Erda Avriyanti, ${ }^{5}$ Dede Suhendi ${ }^{6}$ \\ ${ }^{1}$ Department of Biomedical Sciences, Faculty of Medicine, Universitas Padjadjaran, Bandung, Indonesia, \\ ${ }^{2}$ Medical Undergraduate Study Program, Faculty of Medicine, Universitas Padjadjaran, Sumedang, Indonesia, \\ ${ }^{3}$ Department of Microbiology, Faculty of Medicine, Universitas Islam Bandung, Bandung, Indonesia, \\ ${ }^{4}$ Department of Obstetrics and Gynecology, Faculty of Medicine, Universitas Padjadjaran/Dr. Hasan Sadikin \\ General Hospital, Bandung, Indonesia, ${ }^{5}$ Department of Dermatology and Venereology, Faculty of Medicine, \\ Universitas Padjadjaran, Sumedang, Indonesia, ${ }^{6}$ Physics Undergraduate Study Program, Faculty of \\ Mathematics and Natural Science, Universitas Padjadjaran, Sumedang, Indonesia
}

\begin{abstract}
The nosocomial infection could be acquired through airborne disease in the hospital. However, only a particular health center in Indonesia carried out a complete, cautious prevention procedure by utilizing air purifiers due to cost problems. Thus, to minimize the number of nosocomial infections related to bacterial air pollutants, excellent tools with low cost are required to address this problem. We developed an ultraviolet light system within the air purifier at a low cost and the best way to eradicate pathogenic microorganisms in the healthcare center. The study was conducted at the Faculty of Medicine, Universitas Padjadjaran, Bandung in 2009-2010. The room prototype was built from a transparent glass material with two holes at the upper corner as an inlet and outlet pipeline canal. In the middle of the pipeline circulation, a vacuum pump, ultraviolet system, and a cooler were installed so the air will initially flow through those devices before being re-circulated into the room through the pipeline's inlet hole. A fan was set on the room floor, and several ten-centimeter apart, Petri dishes containing microbial growth medium were placed. The microbial colonies from the room with and without the installed ultraviolet system in the air purifier were then compared for analysis. The result showed that an air purifier equipped with an ultraviolet system killed microorganisms $73 \%$ more effective than the air purifier without an ultraviolet system $(\mathrm{p}<0.05)$. In conclusion, employing an ultraviolet system within the air purifier might be effectively killed microorganisms and ultimately reduce nosocomial infection.
\end{abstract}

Keywords: Air purifier, nosocomial infection, ultraviolet system

\section{Pengembangan Air Purifier Ruangan dengan Pemanfaatan Sinar Ultraviolet untuk Membunuh Mikrob Bawaan Udara}

\begin{abstract}
Abstrak
Infeksi nosokomial dapat ditularkan melalui penyakit yang ditularkan melalui udara di rumah sakit. Namun, hanya rumah sakit atau pelayanan kesehatan tertentu di Indonesia yang melakukan prosedur pencegahan infeksi nosokomial secara optimal dengan memanfaatkan air purifier karena kendala biaya. Oleh sebab itu, untuk meminimalkan jumlah infeksi nosokomial yang terkait dengan bakteri pencemar udara diperlukan pengembangan air purifier yang baik dengan biaya yang murah. Kami telah mengembangkan sistem pembersih udara yang terintegrasi sinar ultraviolet dengan biaya rendah untuk mengurangi mikroorganisme patogen di ruang pelayanan kesehatan. Penelitian dilaksanakan di Fakultas Kesehatan, Universitas Padjadjaran, Bandung pada tahun 20092010. Prototipe ruangan dibuat dari bahan kaca transparan dengan dua lubang di sudut atas sebagai ruang instalasi pipa saluran masuk dan keluar. Pada bagian tengah sirkulasi pipa dipasang pompa vakum, sistem ultraviolet, dan pendingin sehingga udara akan mengalir melewati alat-alat tersebut sebelum disirkulasikan kembali ke dalam ruangan melalui lubang masuk pipa. Sebuah kipas dipasang pada prototipe ruangan dan setiap jarak sepuluh sentimeter ditempatkan cawan Petri yang berisi media pertumbuhan mikrob. Koloni mikrob dari ruangan model dengan dan tanpa sistem ultraviolet yang terpasang di air purifier, kemudian dibandingkan untuk dianalisis. Hasil penelitian menunjukkan bahwa air purifier yang dilengkapi sistem ultraviolet membunuh mikroorganisme $73 \%$ lebih efektif daripada air purifier tanpa sistem ultraviolet $(\mathrm{p}<0,05)$. Simpulan, penggunaan sistem ultraviolet dalam air purifier efektif membunuh mikroorganisme dan pada akhirnya dapat mengurangi infeksi nosokomial.
\end{abstract}

Kata kunci: Air purifier, infeksi nosokomial, sistem ultraviolet 


\section{Introduction}

Nosocomial infection is acquired differently from common illnesses while undergoing hospital or healthcare treatment. It then developed in a patient for over 48 hours after admission. The hospital environment is capable of triggering nosocomial infection that worsened a patient's illness. ${ }^{1,2}$ One of the pathways of nosocomial infection is an airborne transmission that can cause respiratory tract infections. ${ }^{3}$ Airborne infections are transmitted through the pathogen or dust circulated from the hospital ventilation system. ${ }^{4}$ The guidelines have recommended airborne precaution as one way of preventing hospital-acquired infections.5,6 Environmental care management of health facilities has managed to support hospital hygiene, including cleaning and decontamination..$^{7-9}$

Implementation of nosocomial infection prevention in Indonesia's healthcare facilities is still regarded as a huge burden due to cost issues. ${ }^{6}$ Currently, a non-ultraviolet (non-UV) air purifier imported from foreign countries is used in Indonesian's hospital, such as a plasma air conditioner with a very expensive cost of 400 USD for one unit in a wardroom. This price is not affordable for middle and lower-level health care services such as primary health care or regional hospitals. As a consequence, cheap air purifiers that can be used automatically in multiple rooms are preferred. ${ }^{3}$ Excellent and practical tools are necessary to fulfill this requirement. The use of UV rays might be the best way to kill microbes because UVs can kill microorganisms at a certain power..$^{9-12}$

Our study proposed one way to reduce the number of microorganisms using a UV system installed in the ductal ventilation system in a prototype room. This air purifier design has low cost and provides good efficiency, effectiveness, automation, and easy to modify and implement elsewhere. ${ }^{13-15}$

\section{Methods}

This study was conducted at the Faculty of Medicine of Universitas Padjadjaran Bandung from 2009 to 2010. We created two types of prototype room. The first type was installed with a UV system air purifier, while the other was not. Subsequently, these distinct rooms were compared. All information, including the room's circulation framework and microorganism type that most likely causes nosocomial infection, were gathered from a previous study. The prototype room was made of an acrylic cube placed outside the laboratory with a temperature measured at $28^{\circ} \mathrm{C}$. The observation was conducted at $7.00-$ 8.30 AM (prototype room using UV system air purifier) and at 8.30-10.00 AM (prototype room not using UV system air purifier) for two days consecutively. The design of the prototype room is shown in Figure 1. The prototype room consisted of two holes at the upper corner as an inlet and outlet pipeline canal. At the middle of the pipeline circulation, a vacuum pump, UV system, and a cooler were installed so the air will initially flow through those devices prior to being re-circulated into the room through the pipeline's inlet hole. A fan was set on the floor of the room, and several ten-centimeter apart, Petri dishes containing microbial growth medium were placed.

The type of lamp used is a germicidal UVC lamp in the wavelength region of $200-280 \mathrm{~nm}$. This UVC lamp has 1 inch (0.01274 m) diameter. The UVC lamp was placed inside the UV chamber built from PVC with 2 inches $(0.0254 \mathrm{~m})$ diameter, coated with aluminum foil, and equipped with an electric switch. The UV chamber's diameter size determined by the maximum air velocity allowed to pass the UV lamp $(<2 \mathrm{~m} / \mathrm{sec})$. The estimated air velocity that passes through the UV lamp, generated by the vacuum pump is $0.31 \mathrm{~m} / \mathrm{sec}$ air velocity, which complies with the requirement $(<2 \mathrm{~m} / \mathrm{sec})$.

Both rooms were treated by healthy human coughing, sneezing, and chatting to ensure airborne microorganisms mixed in the prototype room. The growth of microorganisms observed by counting the number of colony-forming units (CFU) on the blood agar media placed in a different position. Colony identification was performed by Gram staining with crystal violetiodine complex and safranin counterstain and a biochemical test before and after the operation of air purifier at minute 0 and 6o, respectively. ${ }^{16}$ The amount of microorganism estimated that the density of microorganism fell on the surface of an area per one place's cubic foot. ${ }^{17}$

The data showed in mean \pm SD. The number of colonies from each minute analyzed with a student $\mathrm{t}$ test.

\section{Results}

The difference between UV and non-UV system air purifiers, microbial aerosol generated from 


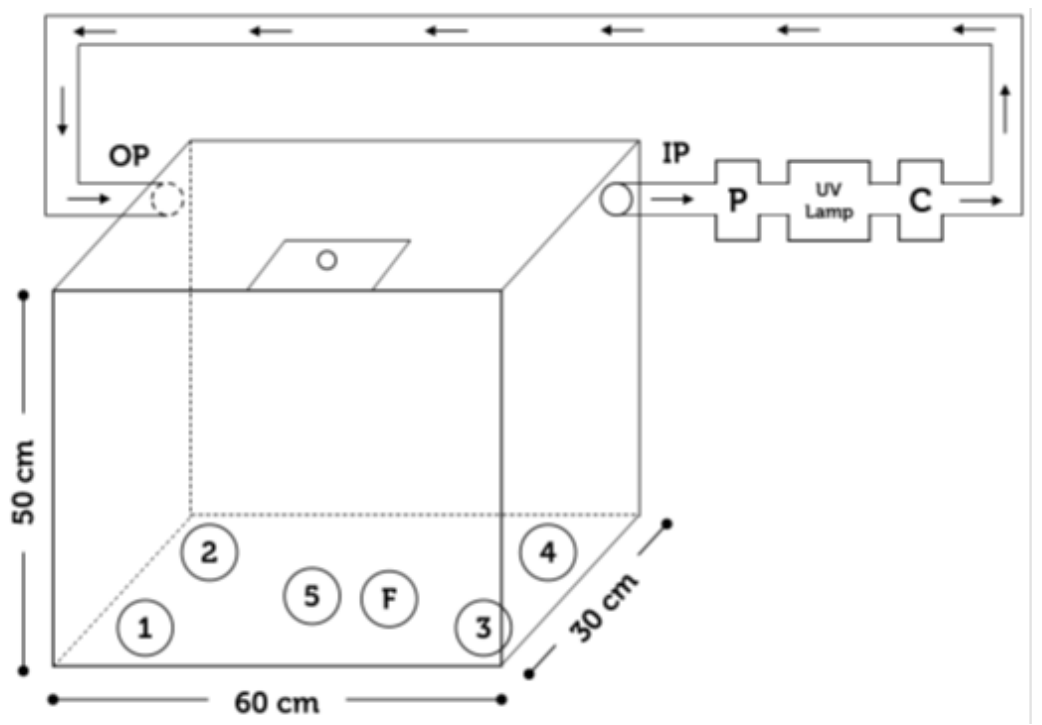

Figure 1 Trend Analysis Plot for Dengue Cases based on Linear Trend Model

The room was built with an acrylic cube with volume size of $0.09 \mathrm{~m}^{3} ; 1-5$ : blood agar media placed in a different position, the corner and center of the room; $\mathrm{F}=\mathrm{fan} ; \mathrm{IP}=$ inlet pipe; $\mathrm{OP}=$ outlet pipe; $\mathrm{C}=$ cooler; $\mathrm{p}=$ vacuum pump

healthy human coughing, sneezing, and chatting introduced and mixed with indoor air within each prototype room (Figure 1). The colony count on this step was noted in the minute o treatment result. After microbial aerosol mixed with the indoor air, the air purifier device operated for 60 minutes. By the end of this process, the colony count (CFU) was noted in the minute 60 treatment result. Statistical analysis was performed to find the significant difference between those treatments in each room. Our evaluation of the colony count demonstrated significantly fewer colonies after operating the air purifier in a prototype room with a UV system air purifier (Table 1).
The number of colony counts at minute o, day 1 in the room installed with UV system air purifier was more significant than the other room. Statistical analysis showed a significant colony count decrease in the UV system air purifier room, with effectiveness value reaching $73 \%$ $(\mathrm{p}<0.05)$. In contrast, there was no significant difference between 0 and 60 minutes in a nonUV system ( $p>0.05$, Figure 2). Table 2 compares the significant difference in the effectiveness between UV and non-UV system air purifiers. Total bacterial colony count in the prototype room with and without UV system air purifier at minute $o$ and minute 60 after turning on the device presented in Figure 1. The colony count in

Table 1 Colony Count Comparison between UV and Non-UV System Air Purifier

\begin{tabular}{lcccc}
\hline \multirow{2}{*}{ Position } & \multicolumn{2}{c}{ UV System } & \multicolumn{2}{c}{ Non-UV System } \\
\cline { 2 - 5 } & mnt-o & mnt-6o & mnt-o & mnt-60 \\
\hline 1 & 46 & 21 & 7 & 7 \\
2 & 26 & 8 & 12 & 5 \\
3 & 78 & 6 & 14 & 29 \\
4 & 47 & 15 & 13 & 3 \\
5 & 30 & 4 & 9 & 34 \\
Mean \pm SD & $45.4 \pm 20.5$ & $10.8 \pm 7.05$ & $11 \pm 2.91$ & $15.6 \pm 14.69$ \\
Student t test & \multicolumn{3}{c}{0.511} \\
\hline
\end{tabular}

Note: the data is in CFU; mnt-o=minute 0 ; mnt-60=minute 60 



Figure 2 Total Bacterial Colony in Minute o and Minute 60

Prototype room using UV system air purifier (A). Prototype room without UV system air purifier (B). ${ }^{*} \mathrm{p}<0.05$; $\mathrm{NS}=$ not significant

the prototype room with a UV system air purifier tended to decrease in contrast to the prototype room with a non-UV system air purifier, which increased slightly.

Furthermore, we performed the identification of colonies that were found. The result showed that there were around 25 different microorganism colonies in the indoor air of the prototype rooms, as summarized in Table 3. Circular colony form and bacilli cell form were found the most among other forms, while no rhizoid form was found. Besides, Gram-positive bacteria that appeared purple after Gram staining treatment were found dominant to Gram-negative bacteria, which decolorized and appeared in pink following such treatment.

\section{Discussion}

One way to reduce the number of nosocomial infections is by controlling airborne transmission. This study showed that the UV system air purifier's effectiveness was $73 \%$, in contrast to the literature, which reached $99 \%{ }^{18}$ This might occur due to the difference in the lamp's electrical power, which could be resolved by increasing the power accordingly. As for the non-UV installation, microorganism growth tends to be statically ascending because the substrate's presence grows, as in damp plumbing. The mechanism of UV radiation as a disinfectant can be explained through DNA activity. ${ }^{11}$ UV radiations were absorbed between the wavelengths of 250 and

Table 2 Installation of UV System Air Purifier is More Effective in Controlling Airborne Bacteria than Non-UV System

\begin{tabular}{|c|c|c|c|c|c|}
\hline \multicolumn{2}{|c|}{ UV System } & \multirow[b]{2}{*}{$\begin{array}{c}\text { Efectivity } \\
\text { (\%) }\end{array}$} & \multicolumn{2}{|c|}{ Non-UV System } & \multirow[b]{2}{*}{$\begin{array}{c}\text { Efectivity } \\
\text { (\%) }\end{array}$} \\
\hline $\begin{array}{l}\text { Mean } \\
\text { mnt-o } \\
\text { (CFU) }\end{array}$ & $\begin{array}{c}\text { Mean } \\
\text { mnt-6o } \\
\text { (CFU) }\end{array}$ & & $\begin{array}{l}\text { Mean } \\
\text { mnt-o } \\
\text { (CFU) }\end{array}$ & $\begin{array}{c}\text { Mean } \\
\text { mnt-6o } \\
\text { (CFU) }\end{array}$ & \\
\hline 31 & 8.4 & 73 & 13 & 14.5 & 11 \\
\hline
\end{tabular}

Note: $\mathrm{mnt}-\mathrm{O}=$ minute $\mathrm{o}$; $\mathrm{mnt}-6 \mathrm{o}=$ minute $60 ; \mathrm{CFU}=$ colony forming unit

Table 3 Characteristics of 25 Different Species of Microorganism Colonies Found in Medium

\begin{tabular}{lcccccccccc}
\hline & \multicolumn{3}{c}{ Colony Form } & & & Gram & \multicolumn{3}{c}{ Cellular Form } \\
\cline { 2 - 9 } & Cir & Irr & Fil & Rhiz & + & - & $+/-$ & Bac & Coc & Cbac \\
\cline { 2 - 10 } $\begin{array}{l}\text { Colony } \\
\text { number }\end{array}$ & 18 & 6 & 1 & 0 & 22 & 2 & 1 & 20 & 4 & 1 \\
\hline
\end{tabular}

Note: Cir=circular; Irr=irregular; Fil: filamentous; Rhiz=rhizoid; Bac: bacilli; Coc=cocci; Cbac: coccobacilli 
$260 \mathrm{~nm}$. This absorption led to the formation of bonds between the adjacent thymine within the DNA chain. The DNA replication was blocked by thymine during the process of cell division. Thus, the effectiveness rate of bacterial destruction is also affected by the time that is required for DNA destruction..$^{10,11}$

The fundamental difference in these two prototype rooms was the presence of UV lamps. With low cost and easy machinery, the UV system has more advantages. For larger scales, such as in hospitals, more complex design criteria are required. The ductal ventilation system's benefit is that if there were an increase in the required space, it would only increase the installation cost. UV chamber and cooler can be used alternately, depending on the room's condition, such as the number of people in the room, microbial virulence level, and the need for sterilization. So, the device in one room is running at a specific time only. In other words, not all rooms were cleaned together.

The automaticity concept is expected by using a microcontroller. This tool can simplify the installation that is utilized in multiple rooms by detecting specific parameter changes, such as colony count or room temperature change. However, this study has used a timer that only ensures the tool runs within a preferred time, thus enhancing the study's accuracy in terms of time control.

There are some essential things to be considered regarding when to apply this UV system air purifier. Specifically, the number of visits and the number of people attended the room. Those factors will determine how many times the tool will run. The most visited hours in this setting were between 8.00-12.00 AM, so then the tool can run for 4 hours a day. There were cost consequences if the system is used in hospitals, particularly emerging waste products (used UV lamps, water from the cooler), and lifetime costs. These costs will depend on the endurance of the lamp and the quality of the maintenance. This problem can be solved by using wastewater for a cooler water source while recycling the UV lamp would be useful.

Eradication of mixed colonies this way would ensure the device's quality in reducing various types of bacteria, similarly to the condition in hospitals, where nosocomial infections commonly caused by opportunistic bacteria, that under normal conditions are not pathogenic. Still, because a person's immune condition is compromised, the bacteria can cause illness. Thus, device testing is not restricted to pathogenic bacteria but tends to varied bacteria in the air.,19

The catalase and coagulase tests performed specifically for colonies to identify the staphylococci groups and distinguish them from the streptococci groups. ${ }^{20}$ This is important, considering these groups of bacteria have had high resistance levels and can cause various diseases. In addition, fungi with smooth hyphae were found in the blood media.

\section{Conclusion}

Employing an ultraviolet system within the air purifier might be effectively killed microorganisms and ultimately reduce nosocomial infection.

\section{Conflict of Interest}

The authors declare no conflict of interests.

\section{Acknowledgment}

We thank the Ministry of Research, Technology, and Higher Education of the Republic of Indonesia, which supported this work.

\section{References}

1. Khan HA, Ahmad A, Mehboob R. Nosocomial infections and their control strategies. Asian Pac J Trop Biomed. 2015;5(7):509-14.

2. Khan HA, Baig FK, Mehboob R. Nosocomial infections: epidemiology, prevention, control and surveillance. Asian Pac J Trop Biomed. 2017;7(5):478-82.

3. Tabatabaei SM, Behmanesh Pour F, Osmani S. Epidemiology of hospital-acquired infections and related anti-microbial resistance patterns in a tertiary-care teaching hospital in Zahedan, southeast Iran. Int J Infect. 2015;2(4):e29079.

4. Joseph A. The impact of the environment on infections in healthcare facilities [Internet]. Concord: The Center for Health Design; 2006 July [cited 2020 July 1]. Available from: https://www.healthdesign.org/ system/files/Joseph_The_Impact_of_ Environment_2006.pdf.

5. Mehta Y, Gupta A, Todi S, Myatra S, Samaddar DP, Patil V, et al. Guidelines for prevention of hospital acquired infections. 
Indian J Crit Care Med. 2014;18(3):149-63.

6. Murni I, Duke T, Triasih R, Kinney S, Daley AJ, Soenarto Y. Prevention of nosocomial infections in developing countries, a systematic review. Paediatr Int Child Health. 2013;33(2):61-78.

7. Pratt RJ, Pellowe C, Loveday HP, Robinson N, Smith GW, Barrett S, et al. The epic project: developing national evidencebased guidelines for preventing healthcare associated infections. Phase I: guidelines for preventing hospital-acquired infections. $\mathrm{J}$ Hosp Infect. 2001;47(Suppl):S3-82.

8. Siegel JD, Rhinehart E, Jackson M, Chiarello L; Health Care Infection Control Practices Advisory Committee. 2007 guideline for isolation precautions: preventing transmission of infectious agents in health care settings. Am J Infect Control. 2007;35(10 Suppl 2):S65-164.

9. Agency for Healthcare Research and Quality. Environmental cleaning for the prevention of healthcare-associated infections (HAI) [Internet]. Rockville: Agency for Healthcare Research and Quality; 2014 August 25 [cited 2020 August 5]. Available from: https:// effectivehealthcare.ahrq.gov/products/ healthcare-infections/research-protocol.

10. Heidarinejad M, Srebric J. Computational fluid dynamics modelling of UR-UVGI lamp effectiveness to promote disinfection of airborne microorganisms. World Rev Sci Technol Sustain Dev. 2013;10(1/2/3):78-95.

11. Nardell E, Vincent R, Sliney DH. Upper-room ultraviolet germicidal irradiation (UVGI) for air disinfection: a symposium in print. Photochem Photobiol. 2013;89(4):764-9.

12. Jinadatha $C$, Quezada R, Huber TW, Williams JB, Zeber JE, Copeland LA. Evaluation of a pulsed-xenon ultraviolet room disinfection device for impact on contamination levels of methicillin-resistant Staphylococcus aureus. BMC Infect Dis. 2014;14:187.

13. El-Batal AI, Mosalam FM, Ghorab MM, Hanora A, Elbarbary AM. Antimicrobial, antioxidant and anticancer activities of zinc nanoparticles prepared by natural polysaccharides and gamma radiation. Int $J$ Biol Macromol. 2018;107(Pt B):2298-311.

14. Bolashikov ZD, Melikov AK. Methods for air cleaning and protection of building occupants from airborne pathogens. Build Environ. 2009;44(7):1378-85.

15. Memarzadeh F, Olmsted RN, Bartley JM. Applications of ultraviolet germicidal irradiation disinfection in health care facilities: effective adjunct, but not standalone technology. Am J Infect Control. 2010;38(5 Suppl 1):S13-24.

16. Mulvey D, Redding P, Robertson C, Woodall C, Kingsmore P, Bedwell D, et al. Finding a benchmark for monitoring hospital cleanliness. J Hosp Infect. 2011;77(1):25-30.

17. Sherlock O, O'Connell N, Creamer E, Humphreys H. Is it really clean? An evaluation of the efficacy of four methods for determining hospital cleanliness. J Hosp Infect. 2009;72(2):140-6.

18. Green CF, Scarpino PV. The use of ultraviolet germicidal irradiation (UVGI) in disinfection of airborne bacteria. Environ Eng Policy. 2001;3(1):101-7.

19. Dancer SJ. Controlling hospital-acquired infection: focus on the role of the environment and new technologies for decontamination. Clin Microbiol Rev. 2014;27(4):665-90.

20. Christina N, Ioanna P, George L, Konstantinos $\mathrm{T}$, Georgios A. Risk factors for nosocomial infections in neonatal intensive care units (NICU). Health Sci J. 2015;9(2):9. 